\title{
DISCUSSING THE CONSEQUENCES OF ENVIRONMENTAL EDUCATION ACTIONS IN A CONTEXT OF REFLECTIVE MODERNITY ${ }^{1}$
}

\author{
Vanúzia Sari², Silviamar Camponogara ${ }^{3}$
}

\begin{abstract}
${ }^{1}$ Manuscript extracted from the thesis - Environmental education in a hospital: opportunities and challenges, presented to the Programa de Pós-Graduação em Enfermagem, Universidade Federal de Santa Maria (UFSM), in 2012.

${ }^{2}$ M.Sc. in Nursing. RN., Grupo Hospitalar Conceição. Porto Alegre, Rio Grande do Sul, Brazil. E-mail: nuzia_sari@yahoo.com.br

${ }^{3}$ Ph.D. in Nursing. Professor, Programa de Pós-Graduação em Enfermagem, UFSM. Santa Maria, Rio Grande do Sul, Brazil. E-mail: silviaufsm@yahoo.com.br
\end{abstract}

\begin{abstract}
Objective: to discuss the reasons why the results of environmental education in hospitals do not correspond to the expected based on the concepts of Risk Society and Reflective Modernity, and pointing out alternatives for more effective educational actions in these institutions. Method: this was a qualitative research using a case study method by interviewing nine workers from the Environmental Education Nucleus of a hospital group. The data were collected by documentary research and semi-structured interview and analyzed by content analysis.

Results: the two categories showed that some elements related to Reflective Modernity contributed to the low effectiveness of environmental education actions in hospitals. These included: the influence of abstract systems (specialists) regarding the thinking of individuals; The existence of protective cocoons, reflexivity without reflection, complicity and generalized irresponsibility in the face of ecological risks, and also the segmentation of the environments, which leads to the pluralization of the self in various selves.

Conclusion: it is recommended to use educational experiences based on sensitivity, life and art, accompanied by reflection. This would make it possible to break with this logic of self-confrontation with environmental risks, without weaving a reflection on them, which is typical of Reflective Modernity. In addition, it is suggested that health institutions locally adopt and, locally, a sound pro-environmental policy. DESCRIPTORS: Environment. Nursing. Environmental education. Health education. Education, Nursing.
\end{abstract}

\section{DISCUTINDO AS CONSEQUÊNCIAS DAS AÇÕES DE EDUCAÇÃO AMBIENTAL EM UM CONTEXTO DE MODERNIDADE REFLEXIVA ${ }^{1}$}

\section{RESUMO}

Objetivo: discutir, com base nas concepções de Sociedade de Risco e de Modernidade Reflexiva, as razões pelas quais os resultados da educação ambiental em hospitais não correspondem ao esperado, apontando alternativas para ações educativas mais efetivas nessas instituições.

Método: tratou-se de pesquisa qualitativa, do tipo estudo de caso, tendo como entrevistados nove trabalhadores do Núcleo de Educação Ambiental de um grupo hospitalar. Os dados foram coletados por pesquisa documental e entrevista semiestruturada e analisados por análise de conteúdo.

Resultados: as duas categorias originadas evidenciaram que alguns elementos relacionados à Modernidade Reflexiva contribuíram para a pouca efetividade das ações de educação ambiental nos hospitais. Entre eles, incluíram-se: a influência de sistemas abstratos (especialistas) sobre o pensamento dos indivíduos; a existência de casulos protetores, de reflexividade sem reflexão, de cumplicidade e irresponsabilidade generalizada diante dos riscos ecológicos e, ainda, a segmentação dos ambientes, que leva a pluralização do eu em diversos "eus".

Conclusão: recomenda-se o uso de experiências educativas baseadas na sensibilidade, no vivido e na arte, acompanhados de reflexão. Isto possibilitaria romper com essa lógica de autoconfrontação com riscos ambientais, sem tecer uma reflexão sobre eles, que é típica da Modernidade Reflexiva. Além disso, sugere-se que as instituições de saúde adotem e defendam, localmente, uma sólida política próambiental.

DESCRITORES: Meio ambiente. Enfermagem. Educação ambiental. Educação em saúde. Educação em enfermagem. 


\section{DISCUTIENDO LAS COSECUENCIAS DE LAS ACCIONES DE EDUCACIÓN AMBIENTAL EN UN CONTEXTO DE MODERNIDAD REFLEXIVA}

\section{RESUMEN}

Objetivo: discutir con base en las concepciones de Sociedad de Riesgo y modernidad reflexiva, las razones por las cuales los resultados de la educación ambiental en hospitales no corresponden a lo esperado, apuntando alternativas para acciones educativas más efectivas en estas instituciones.

Método: investigación cualitativa, del tipo de estudio de caso teniendo como entrevistados nueve trabajadores del Núcleo de Educación Ambiental de un grupo hospitalario. Los datos fueron recolectados por investigación documental y entrevista semiestructurada y analizados por análisis de contenido.

Resultados: las dos categorías originadas evidenciaron que algunos elementos relacionados a la Modernidad Reflexiva contribuyeron para la poca efectividad de las acciones de educación ambiental en los hospitales. Entre ellos, se incluyeron: la influencia de sistemas abstractos (especialistas) sobre el pensamiento de los individuos; la existencia de capullos protectores, de reflexividad sin reflexión, de complicidad e irresponsabilidad generalizada mediante los riesgos ecológicos y, aun, la segmentación de los ambientes, que lleva a la pluralización del yo en sus diversos "yos".

Conclusión: se recomienda el uso de experiencias educativas basadas en la sensibilidad, en lo vivido y en el arte, acompañados de reflexión. Esto posibilitaría romper con esa lógica de auto confrontación con riesgos ambientales, sin tejer una reflexión sobre ellos, que es típico de la Modernidad Reflexiva. Además, se sugiere que las instituciones de salud adopten y defiendan, localmente, una sólida política pro-ambiental.

DESCRIPTORES: Ambiente. Enfermería. Educación ambiental. Educación en salud. Educación en enfermería.

\section{INTRODUCTION}

The growing world-wide debates around an alarming environmental crisis and the media exploitation of countless disasters have contributed to the greater dissemination of knowledge regarding the ecological risks to which we are all exposed to. However, this does not necessarily mean a reflection on them, but rather a greater self-confrontation with the possibility of their occurrence.

Today we live in the so-called Reflective Modernity, in which the dangers arising from industrial society begin to dominate public debates (what is termed as self-confrontation). However, society continues to make decisions and carry out actions that produce and legitimize those same threats and risks that it cannot control. In other words, modern societies are confronted with the foundations and limits of their own model, to the exact degree to which they do not change. It is not reflected in its effects, giving continuity to the post (what is termed as Reflexivity of Modernity). ${ }^{1}$ The term Risk Society demonstrates the impossibility of attempting to protect today's society from the dangers of "nature" that is industrially integrated and so that there is no way to throw such hazards (at first sight, hazards of nature) only to the "other" of the environment, since environmental hazards also pose social, medical, economic, political and systemic threats, containing a globalizing, supranational tendency that is independent of classes. ${ }^{2}$

It should be noted that the environmental impact of an industry shaped by an instrumental rationality, with its various effects on the health and the coexistence of people, is marked by a deficit of social thought, demonstrated in a general complicity of society and a general irresponsibility of individuals and institutions in the face of the existing crisis. ${ }^{2}$ The current situation demands profound reflections that allow us to reorient the directions and guiding presuppositions of individual and collective consciousness, signaling effective means for the desired changes. In this sense, environmental education (EE) is one of the vehicles, from which humanity can reach more sustainable levels, since it tends to help to integrate the person into reality and a sense of belonging to the world, giving man new views, thoughts and desires. ${ }^{3}$

Undoubtedly, educational activities represent a concrete space for action-reflection, ${ }^{4}$ and for a possible rupture of a state of generalized alienation, disenchantment with the world and loss of control over the meaning of human existence, which can lead to a re-appropriation of the world through the channels of knowledge, ${ }^{5}$ which is why EE is one of the fundamental processes in the search for alternatives to ecological problems. ${ }^{6}$

In the hospital context, however, the actions in this area are almost nil, being presented in a study on the issue, as specific and very limited initiatives, ${ }^{7}$ although in the literature there is the recognition that the reflections from EE activities can motivate more responsible actions for health by the health workers; reordering social practices. ${ }^{8}$ It is recognized that if these spaces of reflection do not exist [or are limited], there is a perpetuation of mechanized and automated conducts; and of banalised discourses about the environmental crisis. ${ }^{8-9}$ Therefore, there is a pressing need to debate the issue in health 
institutions, through a systematic, comprehensive and permanent method of education, ${ }^{10}$ not only concerned with informative actions but also with awareness and reflection.

In spite of this, research correlating health and environmental institutions has been directed in particular to the approach of the epidemiological bias, or approach to quality of life and health promotion, or to the issue of waste from health services ${ }^{8,10-11}$ so that discussions about $\mathrm{EE}$ actions in such institutions correspond to a gap in current literature. What exist are more general studies in other fields of knowledge that, when they discuss EE, they give an idea of paths to be followed in health institutions aswell. ${ }^{12-15}$

However, even though EE practices are implemented in the health area, there is a gap between the act of sensitizing/educating and the consequences thereof. Therefore, it is fundamental to investigate and seek the understanding of the different contexts that affect the perceptual capacity (and responses) of individuals and the possible mechanisms that make them more or less affected by what happens in their environment, ${ }^{3}$ particularly in aspects of Reflective Modernity and the Risk Society. After all, what is there to say when the results of EE's actions are not the ones intended? When there is little attitude change? What mechanisms would influence the condition of inertia, the "laziness" of bodies (individuals) to change their state of movement (I continue to do what I have always done) or rest (this is not about me, it is the other person)?

Authors of Sociology $y^{1-2,16-17}$ believe that we live in a period of Reflective Modernity, in which there is a self-confrontation with risks, without reflection; in which time, space, and place are separated so that global influences the place; in which experts offer statistical security for environmental hazards, or diverge about them and the time of their occurrence; in which we learn not to look at the possibility of risk by putting it in parentheses; in which we learn to shape our behavior, according to the environment in which we are; in which fiction seems more real than reality itself... all this has led EE to stumble in its attempts.

This article aimed to (rightly) discuss the reasons why the results of the EE activities, in hospital contexts, are not precisely those intended in terms of cultural changes and construction of complex environmental knowledge, based on the concepts of Risk Society and Reflective Modernity. It also pointed out ways (types of actions) to be tackled by EE in health institutions, when it seeks to break the self-confrontation, without reflection, typical of
Modernity and the Risk Society of Risk, and characteristic of the current environmental crisis.

\section{METHOD}

A descriptive-exploratory case study, with a qualitative approach performed together with a large hospital group in the South region of Brazil, with $100 \%$ public attendance and education center in the region. The documentary research and the semistructured interview were chosen as data collection techniques, which were finished upon empirical saturation, and the content analysis framework (using the software ATLAS.ti 5.0) was used to analyze the information collected. These steps were carried out between August 2011 and January 2012.

The documentary research accessed documents pertinent to the object of study, among them including: institutional reports, newsletters, course announcements, meeting minutes, materials for the dissemination of seminars, meetings, lectures and technical visits, strategic management agendas, management waste plans etc. The interviews, in turn, were pre-scheduled and held in a reserved place, recorded digitally and subsequently transcribed. They were guided by a script, containing guiding questions about the topic under investigation.

The individuals surveyed included workers from the hospital group in question, who were directly involved with the planning and/or implementation of on-site EE activities. This included: members of the Center for Environmental Education of the hospital group and key informants indicated by them, totaling nine individuals, among them including nurses, education technicians, with different training and techniques in technical work safety. All of them participated in the study, by reading, agreeing and signing a Free and Informed Consent Form.

The research project complied with the requirements of specific national and international legislation for this purpose, and was approved by the Research Ethics Committee with Human Beings of the studied hospital group, under the protocol number 11-127/2011 (CAAE-0156.0.243.164-11). The privacy of the interviewees was ensured by identification by using the "E code", followed by an Arabic number, not necessarily corresponding to the order of the interviews.

The analysis of the data allowed the emergence of four thematic axes, one of which discussed the reasons (the mechanisms, aspects and condi- 
tions), based on questions and concepts of Reflective Modernity and the Risk Society, which meant that actions had not achieved the desired results in terms of change in values, behaviors and attitudes; highlighting possible ways to break with this logic. This axis encompasses two categories, which will be presented and discussed in the following section.

\section{RESULTS}

Not every educational action in the environmental field acts in the same way in all "human bodies", although they apparently exercise the same force on them, since they are the same actions for all, which does not, of course change the present state of rest (the stated: this is the others problem, it's not my problem). This is particularly so because the condition of Reflexivity of Modernity (selfconfrontation without reflection) and its intensity over the individual has a direct influence on its inertia. The proportion of the reaction depends on the "how" an action "touches" each body and its ability to generate reflection, to break with mechanisms of mere self-confrontation with risks.

Thus, when it is intended to address why the results of EE are not those which were intended, it is initially imperative to address issues such as: reflexivity in modern conditions, mechanisms of separation between time, space and place (global influences the place); the existence of abstract systems (the specialists), determining ways to act; the notion of trust, security and risk (putting risks in parentheses, rather than contemplating them), about the end of others (we are all exposed to risks) and the existence of plural and segmented environments (as a consequence of globality, or not in pro-environment lifestyles). ${ }^{1-2,16}$ The discussion of such questions helped to understand the reason for being "this or that" the outcome of the actions of EE. Especially in this study, such prerogatives could be organized into two categories.

\section{"It's the man who smokes, he doesn't see his lungs, so it's okay" - The condition of Modernity to "put the risks in parentheses"}

Category 1 highlighted the idea that, in times of Reflective Modernity, what can go wrong is put aside, it is "left" to the other, considering that its occurrence is, for the imaginary, practically improbable (I'm safe). It is the "smoking man" metaphor who continues to smoke simply because he cannot see his own lungs, believing that the risks are dis- tant, and are for others. Although Modernity itself determines the end of the "other", to the extent that, in a short time everyone will be exposed to the potential dangers of this industrialized and socialized environment without any distinction.

However, when "I am protected" from risks, or rather, when real risks are put in parentheses, so that only the other is threatened, then, in this condition, I do not see myself as part of the system as one of those responsible for the environmental crisis; or rather, I don't change what is already my routine. The problem is that the others also has a similar thought and therefore we have a general irresponsibility, in the face of the crisis, and a complicity generalized in terms of what is put in front of everybody's eyes.

In this research in particular, a good part of the interviewees mentioned that the actions of $\mathrm{EE}$ in the hospitals which, still had as a majority effect, responses like: what do I have to do with it? That's got to do with the others; this problem is the problem of others (E5). In spite of the developed activities (or through them), the discourses of many of those with whom one has worked with have also pointed to a logic in which one does not see themselves as an important part of the system (E6). The following testimonies presented this consideration: [...] they begin to put the guilt in someone's lap [...] I do not think people internalize it as their problem (E5); [...] what do I have to do with it, or even where does it effect me [...] It's not about me [...] (E9); [...] I do not want you to do it, because there is someone watching, I want you to do it as a commitment [...] (E6).

Looking at these excerpts one could understand the reason for the questions: what is missing for these people to feel committed? How do I get the person to realize that it's for themselves?! (E6); or if the activities are available, what is missing so that the result is the long awaited one? Obviously, for different results to break the protective barriers maintained by the people, it would be necessary for EE to go back and to re-discuss what is established for that being, at some point, as a routine, recovering its emotionality before the world, and breaking from its protective cocoon.

This other statement represented how important this encounter with "routine" was in EE's activities: how many others are in the same condition? They arrive for work on time, they punch their card, they go home, then, tomorrow, they come back at the same time, they do the same thing, everything in the same way ... ?! So I tried to change it [...] (E6). When this sensitiza- 
tion is achieved, this redemption of the dimension of belonging to a whole, the individual feels the "weight" of the burden of their responsibilities: [...] the sensation I had when I left that sorting and composting unit was which gave me a burden of responsibility on my shoulders, I have to change! (E6). Only then could he act differently, breaking from the pattern of irresponsibility and widespread complicity.

In this aspect, the use of the aesthetics of art and of the experiences in educational activities seeks to recover this emotional component and the sense of belonging to the world, leaving the protective cocoons (seeing the risk and feeling protected) characteristic of the modern contexts. However, there must be continuous activities or there will be no effects.

The following testimonies expressed an understanding of the necessary continuity in EE: the hospital still does a lot of campaigning [...] the campaign finishes and it's forgotten! [...] the environment cannot be forgotten [...] (E9); [...] I can make the comparison with handwashing ... there is that wave of interest ... where everybody washes their hands, now nobody washes their hands [...] (E3).

This continuity in EE is more important because there is considerable exploitation of environmental disasters in the media today, which contributes to the thought that "this is the reality of other people", "my reality is not so real, not like if it is compared to the other person". So, "my real" is (it may be said) "banal", I am "protected from it" (I trust), I am "in a cocoon" that protects me. One of the interviewees clearly expressed a concern that environmental risks and concrete measures to minimize them (including educational activities) are not trivialized and passed on to the other person: [...] I am afraid when things become fashionable! [...] people tire of fashion! [...] because when you turn on the television, they speak about the environment in a way that seems purposeful, to tire people! [...] I wouldn't want the subject to become... fashionable! (E6).

Another feature of Modernity brought up by the interviewees was a pluralization of environments and available lifestyles, mainly due to the globalizing characteristics of Modernity, which dotted the local spaces of distant influences. In general, individuals live in plural environments and are forced to adopt a specific style or different lifestyles, depending on their identification with a given situation, or according to the pressure exerted on them by the place. This choice can influence the results of educational actions for such individuals, especially if the environment reinforces the personality segmentations of these beings.

This relationship between the action environment of individuals and the lifestyle they adopted is the foundation of category 2.

\section{"The public institution did not see action, and in the private institution there is this stance of thinking twice": pluralization of lifestyles and environmental segmentation}

For some respondents, the fact that EE is implemented in a public or private institution, for example, "seems" to influence the results. In this case, some explanation could be found for the differences in behavior in the face of environmental risks and responsibilities, with the apparent tendency of the public institution (as a structure) to impute the cause of the risks to others, removing (partially or totally) the vision of ecological problems from himself and its action, and with it, the concern with a proenvironmental lifestyle or management. This does not necessarily mean that all individuals behave in this way or that there is a greater environmental "consciousness" in the private organization.

The following statements indicate this ambivalence: [...] I think the community [...] works on the issue of EE. [...] the public health centers that have streams or rivers around them suffer with floods [...]. Here inside you have limitations [...] but I think people have learned a lot [...] (E1); In the public institution I saw no action on the issue of waste in the same city, and no one even spoke; [...]indifferent! [...]. Nothing was said, no training. [...]. Unfortunately, I think, public service isn't valuing it yet! [...] if you go to the private hospital, you already have this pressure from the beginning, so you already have this way of thinking twice about what you are going to do [...] (E3).

Reading statements such as, "not in here, no", or "people have learned a lot," or "nothing in the public... private, has this attitude of thinking twice", we noticed the presence of this difference of "ways of being and acting", depending on the environment in which one is "in" and also on how these environments act on "pressure or lack of" a given stance, of requiring a given behavior. This "pressure" in the middle seems to condition some individuals to fragment their " $\mathrm{I}$ ", or even to disguise their "I", to mask it for an appropriate presentation. It is also possible to argue that an individual who has received so many stimuli to be this way or that, assuming this or that stance, or otherwise, which 
fails to receive them in local data/situations, tends to confuse himself about what is, in fact, their " $\mathrm{I}$ ", or rather, to hide this "I" from others.

The statement below gives an idea of this influence: well, if it's for accreditation we will have to [...] train our workers for a while [...] (E1); [...] the emergency department is crowded, ICU is crowded, there is a queue of patients, so nobody has much time to stop and think about how it would be if you had a policy, an EE idea there in the middle [...] you keep doing it, there is no time to stop and rearrange, and think differently [...] (E2).

In fact, there may be a number of "I's" equivalent to the interaction contexts, but this fragmentation is not mandatory. In certain circumstances, such contextual diversity may even promote the integration of various possibilities of "I's" into a single "I", coining an identity from the positive incorporation of distinct environmental elements.

The statement, below, demonstrated the possibility of an environmental ambivalence which (also) strengthens an "ecological self": I know a lot of people that are department managers here inside and they guide their workers [...]. But she's like that at home too! [...] there is a doctor [...]. She says I do this in my clinic, I separate the garbage and I do not admit that my employee does not do [...]. But it is her stance [...]. Her holiday period finishes [...] in Garopaba, there they have selective collection [...] she brings the recycling with her and puts it in front of her house on the right day at the right time [...] (E6).

It is also possible that, in those environments where there is greater exposure and coexistence with the consequences of environmental risks, there is greater awareness of educational actions in this area, with better results. What is shown in the statement: [...] the staff from the linen department, the people from the laundry were more connected because they suffered a lot because of it [...] they raised discussions and did some work [...] (E2).

\section{DISCUSSION}

Why do EE activities fail to generate the expected or desired effects? The attitude of putting risk in between parentheses, ${ }^{16}$ typical of Modernity, may justify the difficulty encountered by EE in shaping changes in individuals' ways of thinking and acting, since "what is not got to do me", "what seems far from self " occupies no more than "my peripheral or momentary attention", and is soon set aside. After all, when I do not see myself in or as part of it (the ecological crisis), there is no way I can wish or think of a different doing from the already ingrained, already routinized in my daily life. And before the context of Reflexivity, in which I only self-confront with risk, but without reflecting on it, it is difficult to break from this cocoon of indifference that protects me.

Therefore to answer the initial questions, it is necessary first of all for individuals to understand the meaning of living in a context of Reflexivity, ${ }^{1}$ to understand that abstract systems (the experts) nourish the so-called basic trust ${ }^{16}$ that "all is well" (the thought that everything will work out, that the risk is far away and the statistics protect us from its occurrence for millions of years).

These individuals need to become aware of their own protective cocoons (the idea that the risk is for the other person) and the ontological security that surrounds them (the feeling of being safe and secure), which are, in a way are the responsible ones, indeed a "filtering of the risks" of Modernity, as an offer of self-protection. ${ }^{16}$ It remains to be understood that there are ties to others, that life is not free from the externalities of the self, even though it appears to be; or rather, we are all interconnected. It remains to be seen that there is a "make-believe" environment in relation to existential issues, which is based on the discipline of keeping daily routines as they are ${ }^{16}$ distancing the anxiety caused by current ecological dangers.

All of these are mechanisms directly involved in the everyday decisions of individuals regarding the environment, even if they are not to be consciously influenced, and as such should be considered when planning EE. One way of considering them is undoubtedly to use them in educational practices of the so-called decisive moments, ${ }^{16}$ those capable of breaking the routine, that which is accustomed to always do the same thing in the same way, and that would enable a review of the forms of thinking and doing.

The fact is that global risks (including ecological) have become so well known that at the level of daily behavior, no one pays much attention to the problem of how to prevent disasters from happening. In a simple decision, most people push away such a possibility from their lives, erasing it from their daily lives. There is the assumption that things will end well, or else, that in the face of a catastrophe, others will bear their weight (the protective cocoons). It is, in turn, to entrust governments and other organizations with coping with the threats. ${ }^{16}$ 
In this hypotheses, the notion of Reflexivity explains that self-confrontation with risks is a constant, which tends to make them unreflected, converting them solely into a reflection of society, its possible side effect. Unlikely and distant risks assure individuals of the possibility of continuing their lives without great anxieties, as their confrontation may (falsely) be imputed to the other. This notion seems to be safeguarded by information passed on by "abstract systems (the experts)" ${ }^{16}$ who, by monitoring the probabilities of a given risk, create safety references and not infrequently even diverge about their real existence. There is talk of distant, unlikely, yet uncertain risks to a future separated from the present by millions of years.

It must be considered, however, that no matter how much one imputes to the other (the other of the State, the environment, etc.) the obligation to face a possible catastrophe, many of the modern risks have as undeniable characteristic, the totality of its scope, especially in terms of the mechanisms of separation between time-space-place. ${ }^{16}$ Both place, time, and space are no longer organized locally, but are intrinsically intertwined with the globe, sprinkled with external influences. ${ }^{17}$ Ultimately ,these patterns of Modernity indicate and antagonistically determine the end of the idea that there is an "other": there is no longer a way to retreat into (real and symbolic) boundaries of protection that, once, could have been made. In the condition of Modernity and globality, the risks are distributed to all, if not now, later. ${ }^{2}$

In theory, the tendency towards risk globalization gives rise to susceptibilities that are nonspecific in their universality. However, "when everything becomes a threat, in a way, nothing else is dangerous. When there is no way out, it's best not to think about it anymore" ${ }^{2: 43}$ When nothing is dangerous, when you do not think about it, it's practically impossible to "see a problem like yours" even after experiencing educational actions that seek to raise awareness of a logic of planetary interdependence. That is to say, unless such actions become "decisive moments" (balance the routine), they will not be able to go beyond a momentary self-confront with the risks.

Indeed, individuals develop an ontological framework of security of some sort, based on various routines, which function as a defensive shell in their daily lives. In fact, this protective cocoon has, essentially, a sense of "unreality" and not necessarily a conviction of security. It is a parenthesis placed around events that could threaten the integrity of the agent and which, when seriously contemplated, would produce a paralysis of will or a sense of suffocation. ${ }^{16}$

But if the "putting risks in brackets" attitude works as a protective cocoon for the individual, it is asked: Would other results for EE be feasible, other than those (previously) placed by the subjects surveyed? And, what would be necessary for that? In fact, when one thinks of a definitive rupture of the protective cocoon (of course it is not meant that this rupture should involve a paralysis, one should dread), there is a need for EE to involve this disturbance of the routine. Faced with the experience of decisive moments, individuals may be forced to face considerations as of yet kept away from their consciousness by the opinion of abstract systems (the specialists). This confrontation would disturb the routines in a radical way, compelling a rethinking of the fundamental aspects of existence and future projects. ${ }^{16}$

At this point, actions using the aesthetics of experience, the experience of art, and sensitivity tend to be more effective in creating decisive circumstances - those capable of "turning around" and breaking routines. Therefore, protecting yourself from modern risks, such as ecological ones, does not have to mean not caring about them or a "that's the other's problem." In fact, the protective barrier can be broken, temporarily or permanently by events that demonstrate the negative contingencies that are part of the risk, ${ }^{16}$ for example, through an EE capable of "mixing" with the emotionality. The problem is that if these activities are transient, isolated and temporarily limited due to the scarce resources (professional, financial, political, structural) available to those who do them, ${ }^{7}$ it is difficult to reach the "emotional", the "sensitive" of individuals. Thus, generally, they do not go beyond much more than a temporary break in the existing protective shells.

In view of the above, it should be emphasized that a person's expectations (including those of the environmental educators themselves) about the impact of educational activities, such as artistic ones, should not be too high because they usually last a couple of hours; a small time interval compared to a life of non-ecological habits. But even so, under such circumstances, EE can act as an aid, an ignition to a greater awareness of the person about their interactions with the world and occasionally, can lead to a new and deep experience of connection with the environment. Starting from this base, it could be a springboard for the development of strategies in the 
face of current ecological issues. ${ }^{18}$ Of course, behavioral changes tend to be more effective when these activities are encouraged, resumed and revived in a permanent and continuous process. In this condition, (also) permanent ruptures of the protective cocoons we adopt (not looking at the risk as mine) will become viable.

In this sense, it is recommended that there be the presence of an environmental policy that offers a legal, structural, financial and human framework in the health institutions, ${ }^{7}$ capable of guaranteeing continuous EE and exploring sensitivity, poetic, imaginative and lived experiences of frequent activities, involving the workers' collective for more than a few hours, year after year, indefinitely. Only in this way can one respond to a planetary logic.

Nevertheless, when considering, in particular, the possibility of using the lived experience in EE, the encounter with the real, it is important to consider that Modernity - especially due to globalization and time-space undoing mechanisms - can bring (through the media) a reversal of reality. In this connection, there is such an intrusion into everyday consciousness of experiences (real and fictitious) and distant events transmitted by the media that the actual event (that which is next to the individual), when encountered, seems to have a less concrete and meaningful experience than its media representation. ${ }^{16}$ Apparently what is conveyed is much more real and familiar than what is experienced in close quarters.

Looking at this inversion of reality and adding the questions of the emotive individualities, one can arrive at a certain degree of understanding of why the results of educational actions that explore the potential of the real/lived (for example, visits with reflections in the medium of nature), are not always precisely the intended ones; which is not to say that such actions are invalid, on the contrary, they have much potential to generate ruptures. What is emphasized is that just looking at the real may not be enough (visits, for example), since the expressiveness of the manifesto in the media will seem much more real and livelier. It takes a sensitive and reflected exploration of this experience. It is necessary to find ways to continuously touch, the emotionality, the sensitivity of the people. Only in this way, the disruptions in that protective shell will be definitive, because it is not enough to carry out the unrestrained stimulation of the senses and feelings, without reflecting on it. ${ }^{19}$

After all, the media itself has been in charge of effecting this unbridled stimulation. It is unde- niable that, in recent years, environmental issues have gained some prominence in the media, but in terms of exploring its consequences are exposed superficially without much reflection. It seems that the discussion on the distribution of pollutants, toxins, impacts on water, air, soil etc., driven by the natural sciences and presented (colorfully) to the public at present, or moves between the fallacy of biological and Social concerns, or neglects the social and cultural meanings that people impute to these issues. ${ }^{2}$ Similarly, pedagogical and environmental discourses end up enclosed in a kind of talk that repeats itself, insistently, emptied of concreteness. ${ }^{20}$ In any case, they end up banalizing or limiting the theme.

When attempting to perform EE, one must consider all these factors and be concerned with the rescue of the connections between environment and human. It is not enough just to look at the local or global reality, it is essential to feel it, to live it, to reconnect with the world, to capture it, sensibly, to insert itself intimately, in this world. For this, the poetic, aesthetic and playful state has the potential to lead the individual to feel the true life and not be only distracted by facts, ${ }^{21}$ however, only if accompanied by the reflective aspect.

Continuing this discussion, it is necessary to emphasize that, although in Modernity, the risks are more of the others than mine (in their causes and consequences), all individuals are forced to choose a lifestyle from a diversity of options. ${ }^{21}$ Usually, the adopted lifestyles are linked to the specific environments (and their characteristics) of these individuals' actions, and may even be segmented (correspondingly) in correspondence to the segmentation of these environments (different environments may lead, but not necessarily, to the adoption of different lifestyles in each of them.) Thus, the modern segmentation of environments may be the basis of the ambivalence and plurality of lifestyles adopted or demonstrated by individuals, even if they are false "selves" fantasized for each processed social security.

In fact, the environments of social life today are diverse and segmented, above all, in the aspect of the differentiations between the public and the private domain (intimacy of being); each of them is also subject to particular pluralizations. The existence of these multiple environments of action, very often (but not necessarily), tend to segment the lifestyles choices and the activities of individuals, so that modes of action followed in a given context 
may be more or less distinct of those adopted in another, ${ }^{16}$ coexisting for the same individual. After all, "in Modern Society, the self is fragile, brittle, fractured, fragmented" ${ }^{16: 157}$

In this perspective, the diversification of contexts of interaction can lead to a fragmentation of the assumed "styles of being," precisely because in modernity the individual is strongly linked to a variety of encounters and places that demand "appropriate" behaviors. ${ }^{16}$ Therefore, when leaving one encounter and entering another, this individual sensitively adjusts the "presentation of his/her self" in order to correspond adequately to what is demanded in the new situation. ${ }^{16}$ Hence, the justification for a public hospital (for example), educational actions appear to be unsatisfactory or satisfactory for a given period of time when something is wanted (accreditation, for example), while in the private sector, due to the "collections and inspections" tend to (it seems) demonstrate (to the other) a certain degree of involvement. It is emphasized that there is no way to know if this is a true and deep motivation, or what is considered "more appropriate" for that group.

When thinking about this interference of the environment, once again, the importance of the health institution adopts a pro-environmental banner, assuming its responsibility in the face of the ecological crisis. The validation of a local policy enables the gradual construction of an institutional commitment and new ways of thinking, believing and doing, ${ }^{7}$ or rather, in this condition, there will be a pressure mechanism for responsible action, which could influence the structuring of a self that is truly concerned with the question - if a practice based on the recovery of the sensibility and the sense of belonging to the world can be adopted.

Obviously, in the face of the pluralization of environments, there may be both the construction of a positive fixed identity and one that evaporates in an adaptive response to the various contexts. On the occasion of the latter condition, a "false self" overcomes and covers up the true motivations of individuals, their feelings and wishes. ${ }^{16}$ And if there is this cover up one can, to some extent believe in the person's little involvement with what he demonstrates, at first to be worried, talking just for the sake of saying something, because when one masks the original thoughts, feelings and wishes, the individual becomes empty and inauthentic. ${ }^{16}$

In the first case, the individual, once sensitized to a logic of planetary interdependence, even in the face of ambivalent environments or just before them, strengthens a fixed identity, which is maintained before the fragmentation and differentiation of the conjuncture in which it is inserted, and still, that it continually shows itself to the other, translating itself into the concrete and encouraging the other to also act in another way.

Finally, we add to this discussion the possibility that, in those working environments in which environmental risk is more visible and felt, or in which there is an obligation to live with them, individuals feel compelled (until a certain point) to have and to express some concern with the environmental issue; becoming more involved in EE activities and expressing some results in their daily lives.

Faced with all of this, it is thought that EE should act to try to capture this environmental influence on the lifestyles of individuals, seeking to consolidate this "concern for the environment" in the form of a fixed identity, with the ability to maintain, and even to strengthen in the face of the pluralities and fragmentations of the contexts in which beings are inserted. When this does not happen, it is possible that the environmental concern dies with the environmental segmentation, or it is limited to a mask to be used given moments. In this respect, it seems prudent to take up that concrete experience once again, the lived experience, the real, that can become a "decisive circumstance" for those involved and, like any decisive circumstance, "break" the routine, to stop to reflect; paving the way for differentiating and for others to share it.

\section{CONCLUSION}

The results of this research point out that the mechanisms of the High Modernity contribute to the unexpected and ineffective results of the EE actions, particularly those concerning: the influence of the abstract systems (subject specialists) that induce the basic trust that everything will work out and that it is statistically protected from risks; the presence of protective cocoons and ontological security (based on established routines), which filter the risks of modernity, offering selfprotection to individuals (the risk is to the other); the existence of "pretend" environments in relation to environmental issues (the idea that others will be able to deal with the problem); to the condition of the reflexivity of "putting the risks in parentheses" (the risk is self-confronted, but not reflected); to 
the notion of general complicity and widespread irresponsibility around the ecological problem, in which "all are cause and effect and therefore a non-cause"; to the inversion of the environmental reality by the media, determining that the fictitious reality or the other is apparently more problematic and more real than "mine" and the segmentation of environments, which often ends up determining pluralized "I's", capable of assuming environmental behaviors/values, according to the contexts in which they are. All these aspects should be considered and recognized when developing educational activities in the environmental area.

At this juncture, it is recommended that EE explore the "decisive moments", through the use of aesthetic educational experiences, based on the exploration of sensibility, the lived and the art, accompanied by true reflection. This process should be based on an institutional framework that provides political, administrative, human and financial support for actions; "pressuring" the individuals to have differentiated posture and environmental sustainability.

\section{REFERENCES}

1. Beck U. A reinvenção da política: rumo a uma teoria da modernização reflexiva. In: Beck U, Giddens A, Lash S. Modernização reflexiva: política, tradição e estética na ordem social moderna. $2^{\mathrm{a}}$ ed. São Paulo: Editora da Universidade Estadual Paulista; 2012. p. 11-71.

2. Beck U. Sociedade de risco: rumo a uma outra modernidade. 2 ed. São Paulo: Editora 34; 2011.

3. Marcomin FE. Educação ambiental: uma incursão na percepção ambiental e na sensibilização imagética. Rev Eletr Mestr Educ Ambient [Internet]. 2014 [cited 2016 Apr 24]; 31(2):106-26. Available from: https:/ / www.seer.furg.br/remea/article/view/4646

4. Trein ES. A educação ambiental crítica: crítica de que? Rev Contemp Educ. 2012; 7(14):304-18.

5. Leff E. Complexidade, interdisciplinaridade e saber ambiental. Olhar de professor [Internet]. 2011 [cited 2015 Oct 25]; 14(2):309-35. Available from: http:/ / www.revistas2.uepg.br/index.php/olhardeprofessor

6. Oliveira MG, Carvalho LM. Políticas públicas de formação de professores e de educação ambiental: possíveis articulações? Rev Contemp. Educ. 2012; 7(14):252-75.

7. Sari V, Camponogara S. Challenges of environmental education in a hospital institution. Texto Contexto Enferm [Internet]. 2014 [cited 2015 nov 05]; 23(2):469-78. Available from: http://www.scielo. br / scielo.php?script=sci_arttext\&pid=S010407072014000200469\&lng=en\&nrm $=$ iso
8. Camponogara S, Ramos FRS, Kirchhof ALC. Reflexivity, knowledge and ecological awareness: premises for responsible action in the hospital work environment. Rev Latino-Am Enfermagem [Internet]. 2009 [cited 2015 Nov 05]; 17(6):1030-6. Available from:http:/ / www.scielo.br/scielo.php?script=sci_ arttext\&pid=S010411692009000600016\&lng=en

9. Camponogara S, Ramos FRS, Kirchhof ALC. A problemática ecológica na visão de trabalhadores hospitalares. Ciênc Saúde Colet [Internet]. 2011 [cited 2015 Nov 05]; 16(8):3561-70. Available from: http://www.scielo.br/scielo.php?script=sci_ arttext\&pid=S141381232011000900024\&lng=en

10. Camponogara S, Soares SA, Terra MG, Santos TM, Trevisan CM. Nurses involved in management of hospital residues: a descriptive study. Online Braz J Nurs. [Internet]. 2012 [cited 2015 Nov 01]; 11(2):289304. Available from: http:/ / www.objnursing.uff.br/ index.php/nursing/article/view/3621/pdf_1

11. Sari V, Camponogara S. A procura de pontos de mutação na enfermagem: eles existem? Rev Enferm UERJ [Internet]. 2013 [cited 2016 Apr 24]; 21(esp1): 665-70. Available from: http://www.epublicacoes.uerj.br/index.php/enfermagemuerj/ article/view/10050/7835

12. Tsekos CA, Tsekos EA, Christoforidou EI. Ecology, literature and environmental. Education Int Educ Stud [Internet]. 2012 jun. [cited 2016 Apr. 24]; 5(3):18792. Available from: http://dx.doi.org/10.5539/ies. v5n3p187

13. Orsi RFM, Weiler JMA, Carletto DL, Voloszin M. Percepção ambiental: uma experiência de ressignificação dos sentidos. Rev Eletr Mestr Educ. Ambient [Internet]. 2015 [cited 2016 Apr. 24]; 32(1):2038. Available from: http:/ / www.seer.furg.br/remea/ article/view/4708/3258

14. Curtis DJ, Reid N, Reeves I. Towards ecological sustainability: observations on the role of the arts. S.A.P.I.E.N.S [Internet]. 2014 [cited 2016 Apr. 24]; 7(1):115. Available from: http:/ / sapiens.revues.org/1655

15. Curtis DJ, Howdena M, Curtisa F, McColma I, Scrinea J, Blomfield T, et. al. Drama and environment: joining forces to engage children and young people in environmental education. Aust J Environ Educ. 2013; 29(2):182-201.

16. Giddens A. Modernidade e identidade. Rio de Janeiro: Jorge Zahar Ltda.; 2002.

17. Giddens A. As consequências da modernidade. São Paulo: Unesp; 1991.

18. Boeckel JV. Engaging with landscape through artmaking. In: Grieson S, editor. Intersections. 2013 [cited 2015 Nov 05]. Available from: http://www. naturearteducation.org/R/Artikelen/Engaging\%20 with $\% 20$ landscape $\% 20$ through $\% 20$ artmaking_Jan\%20van\%20Boeckel.pdf

19. Duarte JF Jr. O sentido dos sentidos: a educação (do) sensível. 5a ed. Curitiba (PR): Criar Edições; 2010. 
20. Marin AA, Pereira CA, Silveira E. Experiências de "indeterminação": artistas falando a educadores. OPSIS. 2011; 11(1):271-86.
21. Bach Junior J, Marin AA. Educação estética na pedagogia Waldorf: o imaginário e a paisagem interior. Interfaces da Educ. 2012; 3(8):19-34. 